\title{
Sources of Output Growth of the ICT Sector in Vietnam
}

\author{
Dang Thi Viet Duc ${ }^{1, *}$ and Dang Huyen Linh ${ }^{2}$
}

\author{
${ }^{1}$ Posts and Telecommunications Institute, Km 10, Nguyen Trai Str., Hanoi, Vietnam \\ ${ }^{2}$ Vietnam Institute for Development Strategies, Ministry of Planning and Investment of Vietnam
}

\begin{abstract}
Vietnam has early set the strategy to develop ICT as the enabler for social-economic development and the Vietnamese ICT sector has grown significantly over the past 20 years. This paper analyses the development of the ICT sector by examining the sources of output growth and the structural changes in two periods of 2007-2012 and 20122016. The decomposition results show that the growth of the ICT manufacturing sector is attributed to export in both periods. However, the ICT manufacturing export was mainly based on components import; the sector neither could make any technological progress nor could manufacture products for import substitution. The ICT media and content sector's growth was primarily due to technology advancement in 2007-2012 which led to the household demand-based development in the period 2012-2016. The ICT services sector shifted from primarily served government to household demand while technology was also significantly improved. The results of decomposition analysis are consistent with the macroeconomic situation as well as the ICT policies that the Vietnamese government has implemented over the past years. The paper points out the achievements and limitations in the ICT development policies and suggests directions for ICT policymakers in Vietnam in the coming period.
\end{abstract}

Keywords: ICT, sources of growth, structure decomposition analysis, IO, Vietnam.

\section{INTRODUCTION}

According to the definition and classification of Vietnam (MIC, 2019), which is consistent with OECD and UN's classification (OECD, 2009; UN, 2008), the ICT sector has three sub-sectors, including ICT manufacturing, ICT media and content, ICT services. In Vietnam, the ICT sector has grown rapidly in the past years although the development policies are very different for each sub-sector.

The revenue of the information technology industry (hardware, software and digital content) has increased about 20 times, from $\$ 5,220$ million in 2008 to $\$ 102,973$ million in 2018 , and the number of employees in the industry increased nearly 5 times in 10 years (MIC, 2009; 2019). Vietnam has become a major manufacturer and exporter of electronic products in the world, and the export turnover of electronic products has increased by two digits for many consecutive years (GSO 2019). The number of households with computers doubled in 10 years, from 10 computers per 100 households in 2008 to 21 in 2018. By 2018 , nearly $100 \%$ of enterprises have used computers with software applications for their production and business activities. Vietnam's mobile phone subscriber density was growing fast. From a position lower than most developing countries in 2007, the mobile phone subscriber density in Vietnam reached 145 for every 100 people in 2018, which was

*Address correspondence to this author at the Posts and Telecommunications Institute, Km 10, Nguyen Trai Str., Hanoi, Vietnam; Tel: ++84914932612; E-mail: ducdtv@ptit.edu.vn higher than the average of the world and developed countries (ITU, 2019). Vietnam's internet usage density is also higher than other countries of the same economic level, approaching that of the developed countries with 70 people using the internet for every 100 people in 2018 (ITU, 2019). From an application perspective, e-commerce has become an integral part of business operations. The proportion of enterprises receiving orders via social networks reached $49 \%$ in 2019 (Bureau of E-commerce and Information Technology, 2019). Most Vietnamese people watch the news on electronic newspapers, cable TV, and digital television.

The rapid development of Vietnam's ICT in recent years coincided with the progress in development policies in the field. For ICT hardware manufacturing, the integration policies were pushed. In 2007, Vietnam joined the WTO, followed by the signing and implementation of many bilateral and multilateral free trade agreements (FTAs) with countries around the world. The focus of integration policies is to create a free and equal investment and business environment based on international laws. Besides, Vietnam has implemented many policies to encourage foreign investment such as corporate income tax reduction for FDI (foreign direct investment) enterprises. All FDI enterprises get maximised income tax exemption and reduction period of 13 years (4 years of tax exemption and 9 years of tax reduction). For FDI enterprises producing electronic equipment and high technological products, the tax reduction rate is $50 \%$. The tax rate also continuously decreased from $28 \%$ in $2004-2008$ to $25 \%$ in $2009-2013,22 \%$ in $2014-2015$, and $20 \%$ from 
2016 to present (MOF, 2019). Preferential policies are applied conditionally based on the number of jobs created, the scale of sales, export revenues, and whether the FDI investment is in hi-tech parks or not. The local governments receiving investment also granted these firms further preferential land rental incentives. These incentives have attracted thousands of foreign businesses, including many of the world's leading multinational corporations such as Samsung, LG, Intel, Canon, and Panasonic, to invest tens of billions of dollars in Vietnam to produce electronic products and export to the world market (MOF, 2019). ICT export turnover of Vietnam has increased rapidly and changed the face of the ICT hardware sector in the last 10 years.

In the ICT services and the ICT media and content sectors, there was large state investment through government spending projects of ICT applications and state-owned enterprises. This is a part of the overall development policy of the Vietnamese government from 2000 (Vietnam Communist Party Central Committee, 2000) to build ICT as the enabler for socialeconomic development in Vietnam. Public investment typically accounts for about $64 \%$ of total investment in ICT services and ICT media and content sectors. In the last more than 10 years, public investment in these areas has changed in two phases. The scale of public investment capital increased rapidly from $\$ 685$ million in 2007 to $\$ 1,026$ million in 2012. From 2012 until now, the capital plummeted continuously to $\$ 636$ million in 2016 and $\$ 616$ million in 2018 (GSO, 2019). In the field of ICT services, public investment is mainly through spending projects, promoting e-government, ecommerce, and other applications of ICT in the economy. Public investment in the media and content sector focuses on the development and modernization of transmission, radio, and television broadcasting systems.

Since 2013, software and digital content firms, ICT firms operating in the hi-tech zones have been entitled to incentives on corporate income tax, equipment import tax to create fixed assets, export tax, incentives for land, credit, and some other procedures (GOV, 2013). ICT firms are entitled to the business income tax rate of $10 \%$, compared to the ordinary enterprise tax rate of $20 \%$, for 15 years. Income from the execution of new investment projects in concentrated hi-tech zones of ICT firms is granted four first years of tax exemption, a $50 \%$ reduction of the payable tax amount in the next nine years. High-tech employees working in the ICT field are entitled to a $50 \%$ reduction of the personal income tax (GOV, 2016). These incentives facilitate ICT businesses to attract investment, develop production, reduce product prices, and enhance competitiveness.

What were the sources of the development of ICT in Vietnam in the past years? Did these sources reflect the effect of government policies in the field? The objective of this paper is to examine the sources of output growth and the structural shift of the ICT sector over the past years to analyse the successes and constraints in the development of ICT sectors, from which the government policy implications can be drawn. For that aim, the paper uses three input-output (IO) tables of 2007, 2010, and 2016, implementing factor decomposition method as in Roy and Chakraborty (2005), Heng and Thangavelu (2010) as well as Rohman (2013) to analyse impact factors of ICT output growth in two periods of 2007-2012 and 2012-2016.

The structure of this article is as follows. After the introduction, the second part of the paper provides a literature review of sources of ICT output growth. Section 3 presents the research methodology, which is followed by the research results in section 4 . Section 5 is the conclusion of the paper. On one hand, this paper contributes to the literature of sources of ICT growth studies in general, especially in the case of developing countries. On the other hand, it is a rare empirical study of the ICT sector in Vietnam, a country that has been advocating ICT for economic development for many years but its sources of development have not been empirically studied.

\section{LITERATURE REVIEW OF SOURCES OF ICT GROWTH}

There are a few studies on the sources of ICT growth and development. According to the research method, it is possible to indicate two groups of studies on the topic.

The first group, consisting of studies such as Rai and Kurnia (2017), Tan and Leewongcharoen (2005), and Ein-dor, Myer and Raman (1997), used the qualitative method to analyse the factors inducing growth and development of the ICT sector. Although these studies can provide a framework for potential influencing factors of ICT growth, they can not measure the influence or prove the relationship between these factor changes and the growth and development of ICT. 
The second group used the quantitative method. In principle, to analyse the factors affecting the growth and development of industry, models of regression, growth accounting, or factor analysis are often used. A few studies, such as Shirazi (2008), used a regression model on panel data from many countries to identify impact factors of ICT expansion. Most other quantitative studies on the sources of ICT growth and development have so far been based on the structural decomposition analysis (SDA) method.

Structural decomposition analysis based on the input-output (IO) framework aims to distinguish the critical driving forces of change in many kinds of variables over time. Rose and Casler (1996) indicated one attractive advantage of the method, i.e. the method is a pragmatic alternative to econometric estimation while requiring only two 10 tables, one for the initial year and one for the terminal year, of the analysis rather than a time series data of 15 years or more or panel data from many regions or countries. And this is suitable for the ICT sector since ICT statistics remain a challenging area of work. The antecedents of SDA are the various analyses of changes in U.S. IO tables as performed by Leontief $(1941 ; 1953)$. Later on, this technique has been used extensively for economic, international trade, employment, and other socioeconomic indicators [see Rose and Casler (1996) and Nagashima (2018) for a review].

In the ICT sector, Roy and Chakraborty (2005) studied sources of growth of Indian information sectors in the period 1983-1984 to 1989-1990. The authors found that the domestic demand effect was the main factor behind the increased information output. The technological change effect was the second most important contributor to the growth of the Indian information sector. An increase in demand for exports of information goods and services did induce the growth of this sector but it was much less than the domestic final demand. This period also experienced greater dependence on imports due to liberal import policies adopted by the government. Heng and Thangavelu (2010) found that Singapore's information sector grew in tandem with the expansion of export in the first half of the 1990s. By the second half of the 1990s, the sector's growth was based gradually based more on technology and final demand although the export effect was still dominant. Rohman (2013) presented multi-country comparison enabling assessment and evaluation towards ICT sector development in selected countries in the European region. The result shows that the output of the ICT sectors during the period 1995-2000 was heavily influenced by domestic demand and the export effect. Most of the European countries also enjoy a technological change effect, hence there was an increase of the technological level of other sectors to use ICT sector output.

\section{METHODOLOGY}

This study uses the structural decomposition analysis model used in Roy and Chakraborty (2005), Heng and Thangavelu (2010) as well as Rohman (2013). The basic idea of this method is to analyse the growth of output of a certain industry by the elements built into the output calculation. The measurement allows decomposing output growth by intermediate demand, final demand, import, export, and other basic factors. This means that any change in economic or industrial output between the two times can be explained by the changes in influencing factors. Roy and Chakraborty (2005) defined composition factors as follows:

(1) The effect of domestic final demand occurs when an increase in the economic output of a sector is to meet direct and indirect demand in the domestic market.

(2) The effect of import substitution on the output of a sector, both for final demand and for intermediate demand, is calculated by the changes arising in the ratio of import to the demand. This implicitly assumes that imported products can perfectly substitute domestic products.

(3) The export effect occurs when output growth is due to direct and indirect export demand (demand from abroad).

(4) The technological effect shows the change of industries over time due to the change of production technology as well as the replacement of different inputs.

The main equation of an input-output model (Leontief 1986) is as:

$A x+y=x$

where: $x$ is a vector of gross output, $A$ is a matrix of intermediate input, $y$ is a vector of final demand that includes final consumption, gross capital formation, the export of goods and services and negative of import of goods and services, 
With the aim of output growth decomposition as described above, the output of a sector can be attributed in terms of intermediate and final demands as well as export as follows:

$x_{i}=u_{i}\left(d_{i}+w_{i}\right)+e_{i}$

where $x_{i}$ is domestic production of commodity $i, d_{i}$ is domestic final demand for commodity $i, w_{i}$ is intermediate demand for commodity $i, e_{i}$ is exports of commodity $i, u_{i}$ is domestic supply ratio defined by $u_{i}=\frac{x_{i}-e_{i}}{d_{i}+w_{i}}$ i.e. the proportion of intermediate and final demand produced domestically in sector $i$.

For the whole economy and replace the gross domestic demand $(w)$ by the product of the technical factor $(A)$ and the total output $(x)$, we have:

$x=\hat{u} d+\hat{u} A x+e$

After adding the unit matrix, the above equation transforms into:

$x=(I-\hat{u} A)^{-1}(\hat{u} d+e)$

Replace $R=(I-\hat{u} A)^{-1}$, the above equation rewrites into:

$x=R(\hat{u} d+e)$

Output growth can be analysed from the composing factors based on this formula.

The change in ICT output is presented by $\hat{z}\left(x_{1}-x_{0}\right)=\hat{z}\left[R_{1}\left(\hat{u}_{1} d_{1}+e_{1}\right)-R_{0}\left(\hat{u}_{0} d_{0}+e_{0}\right)\right]$

The domestic final demand effect as $\hat{z} R_{1} \hat{u}_{1}\left(d_{1}-d_{0}\right)$

The export effect as $\hat{z} R_{1}\left(e_{1}-e_{0}\right)$

The import substitution effect as $\hat{z} R_{1}\left(\hat{u}_{1}-\hat{u}_{0}\right)\left(d_{0}+w_{0}\right)$

The technology effect as $\hat{z} R_{1} \hat{u}_{1}\left(A_{1}-A_{0}\right) x_{0}$

In this article, the ICT industry is grouped and classified according to the OECD's ICT definition (OECD, 2009) and the International Standard of Industrial Classification (ISIC) (UN, 2008), and Vietnam's classification (MIC, 2019). ICT is divided into three sub-sectors: (1) ICT manufacturing produces electronics, computers and peripheral components, telecommunications devices, instruments and appliances for measuring, checking, testing and navigating; (2) ICT services sector includes the wholesaling of computers, electronics, components, software applications, software services, telecommunications services, postal services, information processing services, computers and telecommunications equipment repair services, and other information services; and (3) ICT media and content sector includes publishing, film, broadcasting, recording, and other information activities.

Vietnam Government Statistics Organization (GSO) released an IO table every 5-6 years from 1989. The study chooses the beginning time from 2007 due to the situation of ICT development and ICT application in the Vietnamese economy. Before that time, the proportion of ICT in the economy was insignificant. Besides, regarding the statistic technique, the sub-sectors in 10 1989, 1996, and IO 2000 were rather different from those of 102007 and IO 2012. From 2016, Vietnam GSO has conducted some changes in the statistics system, so the IO 2017 was not published as being planned. For research, the IO 2016 was updated from data on enterprise survey, export, import, and Household Living Standards Survey (VHLSS) of Vietnam GSO. After that, the Ras method was used to balance the gross output and gross input of the inputoutput framework. This entails adjusting both accounts proportionately based on their technical coefficient share ratios on both input and output sides (Lahr and de Mesnard, 2004; Trinh, Phong, and Quoc, 2018). At the time of this study, the VHLSS 2018 was not available, only VHLSS 2016 was ready. Therefore, the data set to end in 2016. IO tables are converted from current prices to constant prices using sectoral GDP deflators to assess the real change of the ICT industry.

To analyse the sources of ICT growth and structural changes, sectors of the 10 tables are grouped into a portfolio of 27 broader sectors as shown in Table 1 . The criteria used for sectorial consolidation include: (1) the list of 20 official sectors published by the General Statistics Office of Vietnam; (2) the international definition of the ICT sector, i.e. the OECD definition and ISIC (OECD, 2009; UN, 2018); (3) the potential impact of ICT on each economic sector. Among these 27 sectors, there are 3 sectors (N1, N2, N3) of agriculture, 14 sectors (from $\mathrm{N} 4$ to $\mathrm{N} 17$ ) of manufacturing, and 10 sectors (from N18 to N27) of services. In these 27 sectors, 3 sectors belong to ICT while 24 others are non-ICT sectors. The IO table 2007 and 2016 are converted from the current price to 2012constant prices by using sectoral GDP deflators. 
Table 1: List of 27 Grouped Sectors of the Vietnamese Economy

\begin{tabular}{|c|c|c|c|}
\hline Sector & Description & Sector & Description \\
\hline $\mathrm{N} 1$ & Agriculture & N15 & Other manufacturing and processing products \\
\hline $\mathrm{N} 2$ & Forestry & N16 & Electricity and water \\
\hline N3 & Fishing & N17 & Construction \\
\hline N4 & Metal ore and mineral products & N18 & Wholesale and retail trade \\
\hline N5 & Processed foods & N19 & Transportation services \\
\hline N6 & Drinks and cigarettes & N20 & ICT media and content \\
\hline N7 & Textiles and leather products & N21 & ICT services \\
\hline N8 & Wood and paper products & N22 & Finance and Accounting services \\
\hline N9 & Chemical, petroleum, coal, rubber, plastic products & N23 & Services of science, business, employment \\
\hline N10 & Non-metallic mineral products & N24 & Public services \\
\hline N11 & Basic metals and other metal products & N25 & Education services \\
\hline N12 & ICT manufacturing & N26 & Health care services \\
\hline N13 & Machinery, equipment, utensils and their accessories & N27 & Entertainment services and other services \\
\hline N14 & Transport equipment & & \\
\hline
\end{tabular}

SOURCE: Authors' classification.

\section{RESULTS}

\subsection{Output Growth and Structural Characteristics of Vietnamese ICT Sectors}

In 2016, the output of all ICT sectors accounted for $5.26 \%$ of the total output of 27 sectors of the Vietnamese economy (Table 2). Although this portion had increased since 2007, ICT was still a modest sector compared to some traditional Vietnamese sectors such as agriculture $8.99 \%$ (N1), processed foods industry $11.17 \%$ (N5), textiles and leather products $7.95 \%$ (N7) and chemical, petroleum, coal, rubber, plastic products $9.8 \%$ (N9). Among the three Vietnamese ICT sectors, the ICT hardware sector had the highest production proportion. In 2016, the ICT hardware sector contributed $3.53 \%$ of the total output of the economy. The ICT services sector followed in second place. In the last place, the ICT media and content sector contributed only $0.27 \%$.

2007-2012 was the period of the fast growth of ICT manufacturing. The output growth rate of ICT manufacturing was about $19.24 \%$ per year, which was much higher than those of ICT media and digital content and ICT services sectors, at $6.30 \%$ and $6.71 \%$ respectively (Table 3 ). In the same period, the gross output growth of the economy was $8.11 \%$. Therefore, the proportion of ICT manufacturing sector in the gross output of the economy increased, while the proportion of other two ICT sectors decreased. In the ICT manufacturing sector, this growth was attributed to the big investment of many multinational enterprises in electronic manufacturing from 2008. From 2012 to 2016, the output growth rate of the ICT manufacturing sector was $13.83 \%$ that decreased compared to the

Table 2: Gross Output of ICT Sectors in the Vietnamese Economy

\begin{tabular}{|c|c|c|c|}
\hline Year & $\mathbf{2 0 0 7}$ & $\mathbf{2 0 1 2}$ & $\mathbf{2 0 1 6}$ \\
\hline \hline Sector & \% Total economy & \% Total economy & \% Total economy \\
\hline ICT manufacturing & 2.14 & 3.49 & 3.53 \\
\hline ICT media and content & 0.26 & 0.24 & 0.27 \\
\hline ICT services & 1.65 & 1.55 & 5.47 \\
\hline Total ICT & 4.05 & 5.28 & 5.26 \\
\hline Total Economy & 100.00 & 100.00 & 100.00 \\
\hline
\end{tabular}

SOURCE: Authors' calculation. 
Table 3: Annual Growth Rate of ICT Sectors (\%)

\begin{tabular}{|c|c|c|}
\hline Period & $\mathbf{2 0 0 7 - 2 0 1 2}$ & $\mathbf{2 0 1 2 - 2 0 1 6}$ \\
\hline Sector & 19.24 & 13.83 \\
\hline ICT manufacturing & 6.30 & 16.72 \\
\hline ICT media and content & 6.71 & 12.00 \\
\hline ICT services & 13.98 & 13.44 \\
\hline Total ICT & 8.11 & 13.53 \\
\hline Total Economy & & \\
\hline
\end{tabular}

SOURCE: Authors' calculation.

period 2007-2012 but was still higher than the growth rate of the gross output of the economy at $13.53 \%$. As a result, the proportion of ICT manufacturing in the gross output of the economy continued to increase slightly. From 2012 to 2016, both ICT media and content and ICT service sectors achieved higher growth compared to the previous period, at $16.72 \%$ and $12.00 \%$, respectively.

ICT services and ICT media and content sectors are services, so their proportions of value added in the total output are expected high. In 2016, value added in the total output of these two sectors was $34.13 \%$ and $31.75 \%$, respectively; meanwhile, this figure of the ICT manufacturing sector was $19.99 \%$ (Table 4). Another noteworthy point was that although the proportion of value added in sectors' output tended to decrease from
2007 to 2016, the contribution of the ICT sectors to the value added of the whole economy increased (from $3.16 \%$ in 2007 to $4.67 \%$ in 2016). This was due to the fast expansion of ICT sector in Vietnam in the past years.

In general, the Vietnamese ICT sectors had been more open to the international markets. The import and export ratios of the ICT manufacturing sector were very high. The import rates always closely followed the export rates and these two rates increased continuously between 2007 and 2016. In 2016, the export of ICT manufacturing sector accounted for $167.77 \%$ of its output while the import ratio was 159.32\% (Table 5). Combined with data in Table 4 above, it suggested the assembling characteristics of the ICT manufacturing sector of Vietnam, mainly

Table 4: Value Added Proportions of ICT Sectors

\begin{tabular}{|c|c|c|c|c|c|c|}
\hline Year & \multicolumn{2}{|c|}{2007} & \multicolumn{2}{c|}{2012} & \multicolumn{2}{c|}{2016} \\
\hline Sector & $\begin{array}{c}\text { \% of sector's } \\
\text { output }\end{array}$ & $\begin{array}{c}\% \text { of total } \\
\text { economy }\end{array}$ & $\begin{array}{c}\text { \% of sector's } \\
\text { output }\end{array}$ & $\begin{array}{c}\% \text { of total } \\
\text { economy }\end{array}$ & $\begin{array}{c}\text { \% of } \\
\text { sector's } \\
\text { output }\end{array}$ & $\begin{array}{c}\% \text { of total } \\
\text { economy }\end{array}$ \\
\hline \hline ICT manufacturing & 16.41 & 0.88 & 26.25 & 2.57 & 19.99 & 2.26 \\
\hline ICT media and content & 49.36 & 0.32 & 42.37 & 0.28 & 34.13 & 0.34 \\
\hline ICT services & 47.23 & 1.96 & 41.20 & 1.79 & 31.75 & 1.72 \\
\hline Total ICT & 31.09 & 3.16 & 31.36 & 4.46 & 23.98 & 4.67 \\
\hline
\end{tabular}

SOURCE: Authors' calculation.

Table 5: Export and Import Ratios of ICT Sectors

\begin{tabular}{|c|c|c|c|c|c|c|}
\hline Year & \multicolumn{2}{|c|}{2007} & \multicolumn{2}{|c|}{2012} & \multicolumn{2}{c|}{2016} \\
\hline Sector & $\begin{array}{c}\text { Export ratio } \\
(\mathbf{\%})\end{array}$ & $\begin{array}{c}\text { Import ratio } \\
(\mathbf{\%})\end{array}$ & $\begin{array}{c}\text { Export ratio } \\
(\%)\end{array}$ & $\begin{array}{c}\text { Import ratio } \\
(\%)\end{array}$ & $\begin{array}{c}\text { Export ratio } \\
(\%)\end{array}$ & $\begin{array}{c}\text { Import ratio } \\
(\%)\end{array}$ \\
\hline \hline ICT manufacturing & 37.40 & 30.90 & 96.96 & 70.96 & 167.77 & 159.32 \\
\hline ICT media and content & 27.78 & 0.71 & 9.69 & 32.56 & 8.19 & 29.82 \\
\hline ICT services & 4.35 & 5.35 & 4.71 & 3.18 & 4.70 & 2.04 \\
\hline Total ICT & 23.31 & 18.55 & 65.96 & 49.35 & 114.24 & 108.93 \\
\hline
\end{tabular}

SOURCE: Authors' calculation. 
depending on the imported components, assembled product re-export, and the value added was low. ICT media and content sector imported significantly in the 2012-2016 period. In 2012 and 2016, the import rates reached $32.56 \%$ and $29.82 \%$, respectively, while the export rates were approximately $10 \%$. The importexport structure of the ICT services sector was rather stable and low in both phases. This sector was more inward-looking than the other two ICT sectors.

\subsection{The Sources of Output Growth of ICT Sectors}

The above analysis showed that the overall ICT sector of Vietnam rapidly grew in both periods of 20072012 and 2012-2016 with the average annual growth rates of $13.98 \%$ and $13.44 \%$, respectively. However, when looking in detail, the changes in growth and output structure of each ICT sub-sector over two phases were obvious. This section analyses sources of growth and structural changes of each ICT sector in two stages by four components, including import substitution, technological change, domestic demand, and export. The effect is analysed into sub-effects. Import substitution is divided into a substitution for final demand and intermediate demand. The technological effect is considered into technology changes in ICT sectors and non-ICT sectors. The domestic demand is analysed into four sub-factors including household demand, government demand, fixed capital formation, and change in stock. To have a good analysis, this section also compares the sources of growth and structural changes of ICT sectors with those of the whole Vietnamese economy.

\section{a. Period 2007 - 2012}

In the 2007-2012 period, the gross output of the Vietnamese economy grew at $8.11 \%$ per year. The growth of the economy in this period was mainly influenced by export and household demand with contribution percentages were $77.26 \%$ and $21.93 \%$, respectively (Table 6 ). As such, $99.19 \%$ of the output change of the Vietnamese economy was driven by household demand and export effect only. The contribution of other factors was negligible. The decomposition results also showed that the economy did not achieve technological progress in this period.

The ICT sectors shared similarities with the economy in two main sources of growth, which were exports and household demand, but showed a difference in technological effect.

The growth of ICT manufacturing was entirely driven by export, of which the contribution to the sector's output growth over the period reached $142.43 \%$. This result reflected the fact that Vietnam's export of electronic products, phones, communication equipment, computers and peripheral devices of computers increased by 9.51 times from over $\$ 2$ billion in 2007 to nearly $\$ 20.6$ billion in 2012 (GSO, 2007; 2012). However, the Vietnamese ICT manufacturing sector's products could not substitute imported ones. The import substitution effect was largely negative ($42.64 \%$ ) showing the deep dependence of this sector on imported products from other countries in the period 2007-2012. The import of Vietnamese manufacturing ICT sector was for both final demand and intermediate demand and with the effects of $-24.28 \%$ and $-18.36 \%$, respectively. In 2012, Vietnam exported nearly $\$ 12.75$ billion of phones and accessories but also imported $\$ 13.17$ billion of phone and phone components (GSO, 2012).

The ICT manufacturing sector made a modest technological advance in the period of 2007-2012; the technological effect was positive but only contributed $1.06 \%$ to its output growth. The technological effect can be seen in two aspects. First, the technological effect is rooted in the technological advancement in the ICT sector so that more output can be produced on a specific value of the inputs. Second, the technological effect could be realised when other sectors in the economy substitute ICT products for labour or change their output mix from primary input-intensive products to those requiring more high-tech intermediate products for the production. For example, in the banking and insurance sector, many jobs were replaced by computers which were supposed to be more productive than labour, or power generation and transmission network should increase the use of electronics. The decomposition of technological effect in Table 6 showed that both technology effects of ICT sectors at $1.04 \%$ and of non-ICT sectors at $0.02 \%$ were negligible. As such, although the ICT manufacturing of Vietnam could make increased output, its production deeply depended on the FDI corporations. Domestic ICT manufacturing firms did not successfully absorb technology or establish its production for domestic intermediate demand. For the same reason, domestic final consumption did not contribute to the output growth of this sector. Vietnamese people mainly use imported electronic products, for example, Apple iPhone phones while rarely bought locally assembled Samsung phones. This was partly because plenty of electronic products produced in Vietnam were components, not finished consumer products, and 
Table 6: Sources of Growth of ICT Sectors (as a Percentage of Sectoral Output Growth) 2007-2012

\begin{tabular}{|c|c|c|c|c|c|}
\hline Effects & Sub-effects & ICT manufacturing & ICT media and content & ICT services & The economy \\
\hline \multirow[t]{3}{*}{ Import substitution } & & -42.64 & -60.87 & 8.21 & 1.90 \\
\hline & for Final demand & -24.28 & -41.82 & 6.08 & 4.05 \\
\hline & $\begin{array}{l}\text { for Intermediate } \\
\text { demand }\end{array}$ & -18.36 & -19.05 & 2.13 & -2.15 \\
\hline \multirow{3}{*}{$\begin{array}{l}\text { Technological } \\
\text { change }\end{array}$} & & 1.06 & 135.56 & 1.49 & -11.47 \\
\hline & of ICT sectors & 1.04 & 141.65 & 6.80 & 0.43 \\
\hline & of Non-ICT sectors & 0.02 & -6.09 & -5.31 & -11.90 \\
\hline \multirow[t]{5}{*}{ Final demand } & & -0.85 & 30.84 & 65.75 & 32.31 \\
\hline & Household demand & -0.48 & 39.65 & 31.85 & 21.93 \\
\hline & Government demand & 0.05 & -9.26 & 34.71 & 0.31 \\
\hline & Capital formation & -0.45 & -1.51 & -2.05 & 5.37 \\
\hline & Change of stock & 0.03 & 1.96 & 1.24 & 4.70 \\
\hline Export effect & & 142.43 & -5.53 & 24.55 & 77.26 \\
\hline $\begin{array}{l}\text { Sectoral output } \\
\text { growth }\end{array}$ & & 100.00 & 100.00 & 100.00 & 100.00 \\
\hline Annual growth rate & & 19.24 & 6.30 & 6.71 & 8.11 \\
\hline
\end{tabular}

SOURCE: Authors' calculation.

partly due to the policy of multinational corporations investing in Vietnam was to limit the range of products sold in developing markets such as Vietnam.

The outstanding feature of ICT media and content sector was the technological progress in the period of 2007-2012. The contribution of the technological effect reached $135.56 \%$ of which the effect of ICT sectors was $141.65 \%$ and the effect of non-ICT sector was $0.69 \%$. This result matched the fact that Vietnam managed to master many up-to-date radio and television technologies such as DVB-T1, DVB-T2 digital television, interactive digital television, etc. while the economy relatively reduced the use of ICT media and content products as inputs of production. This was a negative sign of digital transformation in business. The large negative import substitution effect (-60.87\%) on the one hand reflected the booming on foreign copyright television programs imported in this period such as the English Premier League, World Cup (the import substitution for final demand is $-41.82 \%$ ). On the other hand, it also cast the fact that the Vietnamese ICT media and content sector had to rely on imported technology products (the import substitution for intermediate demand is $-19.05 \%$ ). The import of new technological television equipment in the sector raised the risk of being further dependent on foreign suppliers in the future but was hardly avoided for a developing country of low technological capacity. The demand of households was the second most important factor, contributing $39.65 \%$ to the sector's growth.

The ICT services sector made small technological progress from 2007 to 2012. The contribution of technology change to the sector's output growth was $1.49 \%$. In fact, from 2009 Vietnam telecommunication corporations such as VNPT, Viettel developed 3G network. However, it took time for the network to complete so the sector did not see a large technological effect in this period. The import substitution effect was $8.21 \%$, so the domestic production of this sector could replace some imported products. Most of import substitution effect came from production for final demand. Similar to the ICT media and content sector, the demand of households was an important factor for the sector's growth, contributing $31.85 \%$. At a lower effect level, the export factor contributed $24.55 \%$. In this sector, the Vietnamese telecom group Viettel, successfully exported telecommunications services to several countries in Asia and Africa. Software exports increased rapidly, from \$131 million in 2008 to \$647 million in 2012 with an average growth rate of $50 \%$ per year (HCA, 2008; 2012). However, like electronic manufacturing production, the Vietnamese software industry in this period is mainly based on outsourcing with low value 
added for the economy. The different point in sources of growth of ICT services in comparison to other ICT sectors in this period was the contribution of government consumption. This was the result of huge governmental spending projects in e-government, e-commerce, and other ICT applications in the economy.

\section{b. Period 2012 - 2016}

From 2012 to 2016, the gross output of the Vietnamese economy grew by $13.53 \%$ per year, which was higher than that of the previous period thanks to some positive changes. Export continued to be the most important source of growth, the export effect being $51.74 \%$. Domestic household demand contributed $19.15 \%$, being the second most important source of gross output growth. Notably, in this period compared to the previous, the Vietnamese economy made technological progress; the contribution of the factor reached $16.31 \%$. Besides, Vietnam managed to produce products, which could replace some imported; the contribution of import substitution factor was $2.49 \%$ higher than that of the period 2007-2012. For the ICT sector, the influence of factors was generally a continuation of the trends that have formed in the period 2007-2012 but there were also positive changes. The data were in Table 7.
The growth of ICT manufacturing was still entirely dependent on export, reflecting the fact that the export of the sector's products continued to increase fast. Export turnover in 2016 reached $\$ 53.5$ billion, which was 2.6 times higher than that in 2012 (GSO, 2012; 2016). However, while the economy had some positive technological change in this period, the sector could not make any technological progress nor its production could replace imported products. Most imports in this period were for intermediate demand of firms. The import for intermediate demand was $-54.48 \%$, out of $61.52 \%$ of the whole import substitution effect. In 2016, Vietnam exported nearly $\$ 34.5$ billion of mobile phones and components but also imported more than $\$ 28.0$ billion of phone components (GSO, 2016). The domestic demand effect on the sector's growth declined compared to the previous period.

The ICT media and content sector continued to make technical progress with the contribution of the technological change factor of $31.35 \%$. Household consumption also continued to be an important contributor to the sector's growth with a contribution of $24.96 \%$. Compared to the previous period, the industry was successful when on one hand, it was able to export services to regional countries and on the other hand, its products began to replace some imported products. The calculation showed both the export effect

Table 7: Sources of Growth of ICT Sectors (as a Percentage of Sectoral Output Growth) 2012 - 2016

\begin{tabular}{|c|c|c|c|c|c|}
\hline Effects & Sub effects & ICT manufacturing & ICT media and content & ICT services & The Economy \\
\hline \multirow[t]{3}{*}{ Import substitution } & & -61.52 & 6.34 & 3.08 & 2.49 \\
\hline & for Final demand & -7.04 & 1.89 & 1.35 & -1.18 \\
\hline & $\begin{array}{l}\text { for Intermediate } \\
\text { demand }\end{array}$ & -54.48 & 4.45 & 1.73 & 3.67 \\
\hline \multirow{3}{*}{$\begin{array}{l}\text { Technological } \\
\text { change }\end{array}$} & & -9.91 & 31.35 & 22.02 & 16.31 \\
\hline & of ICT sectors & -8.30 & 17.63 & 16.84 & -0.02 \\
\hline & of Non-ICT sectors & -1.61 & 13.72 & 5.18 & 16.33 \\
\hline \multirow[t]{5}{*}{ Final demand } & & -18.70 & 36.22 & 55.15 & 29.46 \\
\hline & Household demand & -3.80 & 24.96 & 45.76 & 19.15 \\
\hline & Government demand & -0.50 & 8.47 & 7.21 & 1.50 \\
\hline & Capital formation & -1.96 & 2.29 & 1.75 & 7.01 \\
\hline & Change of stock & -12.44 & 0.50 & 0.43 & 1.80 \\
\hline Export effect & & 190.13 & 26.09 & 19.75 & 51.74 \\
\hline $\begin{array}{l}\text { Sectoral output } \\
\text { growth }\end{array}$ & & 100.00 & 100.00 & 100.00 & 100.00 \\
\hline Annual growth rate & & 13.83 & 16.72 & 12.01 & 13.53 \\
\hline
\end{tabular}

SOURCE: Authors' calculation. 
and the import substitution effect changing from negative in the previous period to positive in this period, at $26.09 \%$ and $6.34 \%$, respectively.

ICT services sector showed a positive transition in terms of sources of growth and structural change. Firstly, the ICT services sector made more technological progress in the period of 2012-2016 than the period 2007-2012 and continued to replace imported products. The contribution of technological and import substitution factors reached $22.02 \%$ and $3.08 \%$, respectively. The $3 G$ network, which began in 2009, was fully developed with many new ICT services in this period. Vietnamese software outsourcing made progress, not only competing with other countries by low labour costs as in the previous period but also by the quality and skills of human resources (ATKearney, $2007 ; 2011 ; 2016)$. There was also a trend of outsourcing firms shifting to make their products. Secondly, the sector could maintain its software outsourcing services and export of telecommunication services to countries in Asia and Africa. The export factor contributed $19.75 \%$ to the sector's growth. The sector also could successfully serve the domestic household demand, which in effect became the most important source of the sector's output growth with contribution percentage at $45.76 \%$. This attributed to the rapid growth of the economy leading to higher expenditure on more and more competitive ICT services of Vietnamese in this period. A notable remark was that, during this period, state investment through spending projects in the ICT services plummeted, so the government consumption factor only contributed $7.21 \%$, ranked fourth among factors instead of the first influential position as in 2007-2012.

\section{CONCLUSION}

Results of the analysis share some similarities with that of previous studies on the sources of ICT output growth such as Roy and Chakraborty (2005), Rohman (2015). Accordingly, as in some other countries, two factors, including household demand and export, are critical contributors to the output growth of Vietnamese ICT. At the same time, the analysis for each sub-sector through two stages 2007-2012 and 2012-2016 also reveals differences in the growth characteristics of the ICT sector of Vietnam in comparison to other countries. When the sources of ICT sector growth are set beside those of the whole economy, the obvious difference in the technological effect of the ICT sector can be noted. These differences partly indicate the current state of the industry of a developing country like Vietnam, partly reflect the impact of government policies described in the introduction of the paper, which are designed to build ICT as the enabler of the socio-economic development of the country.

Firstly, the growth of the ICT manufacturing sector attributed to the export of electronic products, especially mobile phones. This is the evidence for the success of the ICT manufacturing industry as well as the government policies of international integration and FDI attraction in the field. However, the analysis of export and import ratios and growth decomposition indicates that ICT manufacturing export was mainly based on components import; the industry neither could make any technological progress nor could manufacture products for import substitution. This result is consistent with the conclusion of many studies on the role of electronic manufacturing FDI on technological upgrading in Vietnam. For example, Vind (2008) indicated that most FDI electronics factories in Vietnam are 'reproduction factories' with mature technology and a narrow role in basic component manufacturing, so their contribution to skill upgrading is correspondingly narrow. Le and Pomfret (2011) and Huynh et al. (2019) found negative horizontal spillover (intra-industry) and insignificant positive vertical spillover (inter-industry) of FDI firms on the technological advance and productivity of the Vietnamese firms. Vietnam only provides cheap labour for processing, assembling electronic products, and components for foreign technological corporations. The technology externalities from foreign to local firms are limited. Over many years of receiving FDI, the Vietnamese ICT manufacturing sector has not successfully disseminated technological knowledge to move up itself. The sector has not served for the technological advance of other sectors of the economy neither. It should be noted that positive technological spillover of FDI is stated in many studies in different countries such as Liu (2002), Javorcik (2004), Blalock and Gertler (2008), Newman et al. (2015).

Secondly, the government investment policy in the ICT services industry in the form of spending projects for the period 2007-2012 effectively created good momentum for the sector. Government demand was the main source of output growth of the sector in this period. In the latter period of 2012-2016, while government spending in the sector decreased significantly, the Vietnamese government launched support policies in taxes, credit and land, and procedures to encourage the development of the ICT services businesses. In this period, the sector 
development depended on enlarged domestic demand and at the same time, it was able to export services to foreign countries and produced to partially substitute imports. Roy and Chakraborty (2005) suggested that the government can influence the use of ICT through its role as an investor and a consumer, and as a catalyst, strategist, or regulator. The Vietnamese government, as an investor, a consumer, and a regulator, has successfully supported ICT human resources, developed telecommunications and other ICT infrastructures, created and expanded markets for ICT services businesses, promoted competition, and accelerated export.

Thirdly, the government investment policy in ICT media and content in the form of large technological investment projects led to a remarkable change in technology in the sector in the period 2007-2012. This might be also due to certain protection policies leading a less fierce competition in the sector. As a result, in the latter period 2012-2016, the industry was firmly self-reliant in technology and significantly increased exports of products and services to other countries.

Finally, in the analysis of sources of output growth for high-tech sectors such as ICT, the technological effect is of special focus since this effect is expected to lead to disrupted changes in the business and economy for economic efficiency and development. Except the ICT manufacturing, both ICT media and content and media services sectors of Vietnam showed significantly higher technological effects than the whole economy. The technological advances were greater inside the ICT sectors than in other the non-ICT sectors. It is logical; since the ICT sectors need to improve their technology before diffusing to other nonICT sectors. However, it is the technological advance in the latter that ensures the digital transformation in the economy.

The decomposition results above indicate that government policy did support and catalyze the growth and structural change of ICT sectors in Vietnam in the last years. However, some drawbacks imply that government policy can better enhance the sector's development in the coming period.

Firstly, in the ICT manufacturing sector, policy to attract foreign investment in ICT hardware production is still necessary to create output, exports, jobs, and income for low-skilled workers in Vietnam. However, the technological level is the core of Vietnam's manufacturing industry to develop independently, create high value added as well as to serve for technological changes of other sectors in the economy. Vietnam needs to take advantage of FDI inflows in this field to upgrade the technology capacity of domestic firms. The areas of concern are the close linkages between foreign firms and domestic firms, the transfer of production technology, learning management skills, training qualified technical workers. To achieve this goal, Vietnam needs some changes in the focus of its preferential policies for foreign investment. For example, more incentives should be granted to FDI firms using domestic supply, more support to be given to domestic firms with R\&D activities, and the government should ensure that domestic firms in the industry receive equal preferential treatment as foreign firms.

Secondly, government investment policy through ICT products and services consumption projects is still necessary to expand demand for ICT services and media, as well as to create an environment conducive to private investment and effective adoption of ICT for digital transformation. Other preferential policies in taxes, credit, and land, and procedures should continue to support the investment and competitiveness of ICT firms. Besides, for technological advancement in these sectors, these spending projects should come with high technological requirements. Vietnam needs to continue upgrading the technological capacity of the ICT media and content and ICT services sectors to exploit the expanding domestic market size, enhance its diffusion and integration into other sectors so that the role of ICT as the enabler of the socio-economic development can be successfully gained.

This study has a limitation related to the data, which enables the analysis only until 2016 . However, with the available data, the article has analysed the development of ICT in Vietnam in the period of rapid development from 2007 to 2016. From 2017 to now, the economic conditions and policies of the ICT sector show no significant change, so the policy implications are still valid. Recently, the Vietnamese government has launched some important policies related to the development of the ICT industry. Resolution 50-NQ/TW of the Politburo dated August 20, 2019, defines the most important and consistent criteria in attracting foreign investment in the coming time, which includes quality, efficiency, technology, and environmental protection. Decision No. 749/QD-TTg of the Prime Minister dated June 3, 2020, approves a comprehensive the national program digital transformation to 2025 with an orientation to 2030 . 
These two policy documents are expected to have a major impact on ICT development in Vietnam after 2020. The study plans to open the time frame of the research when the data are available.

\section{REFERENCES}

ATKearney. 2007. Offshoring for long-term advantage. A.T. Kearney, Inc., U.S.A.

ATKearney. 2011. Offshoring opportunities amid economic turbulence. A.T. Kearney, Inc., U.S.A.

ATKearney. 2016. On the eve of disruption: A new business model threatens established concepts of offshoring and expands the market. A.T. Kearney, Inc., U.S.A.

Blalock, G., Paul J. G. 2008. Welfare gains from foreign direct investment through technology transfer to local suppliers. Journal of International Economics; 74: 402-421. https://doi.org/10.1016/j.jinteco.2007.05.011

Bureau of E-commerce and Information Technology. 2019. Vietnam E-commerce report 2019. Vietnam Ministry of Industry and Commerce.

Ein-Dor, Phillip, Michael D. Myers, and K.S. Raman. 1997. Information technology in three small developed countries. Journal of Management Information Systems; 13(4): 61-89. https://doi.org/10.1080/07421222.1997.11518143

GOV (Government of Vietnam). 2013. Decree No. 154/2013/ND-CP: On the concentrated information technology park, November 8, 2013.

GOV (Government of Vietnam). 2016. Resolution No. 41/NQ-CP: Tax incentives for the development and application of information. May 26, 2016.

GSO (General Statistics Office of Vietnam). 2007. Statistics yearbook of Vietnam 2007. Hanoi: Statistics Publishing.

GSO (General Statistics Office of Vietnam). 2012. Statistics yearbook of Vietnam 2012. Hanoi: Statistics Publishing.

GSO (General Statistics Office of Vietnam). 2016. Statistics yearbook of Vietnam 2016. Hanoi: Statistics Publishing.

GSO (General Statistics Office of Vietnam). 2019. Statistics yearbook of Vietnam 2019. Hanoi: Statistics Publishing.

HCA (Ho Chi Minh City Computer Association). 2008. Vietnam ICT report 2008. Ho Chi Minh City Computer Association.

HCA (Ho Chi Minh City Computer Association). 2012. Vietnam ICT report 2012. Ho Chi Minh City Computer Association

Heng, T. Mun, and Shandre M. Thangavelu. 2010, Singapore information sector: A study using input-output tables. IPS Working Papers No. 18.

Hien T. N. Huynh, Phuong V. Nguyen, Hoa D. X. Trieu, and Khoa T. Tran. 2019. Productivity spillover from fdi to domestic firms across six regions in Vietnam. Emerging Markets Finance and Trade: 1-17, 2019 https://doi.org/10.1080/1540496X.2018.1562892

Hoi Quoc Le and Pomfret, Richard. 2014. Technology spillovers from foreign direct investment in Vietnam: Horizontal or vertical spillovers? Journal of the Asia Pacific Economy; 16(2): 183201.

https://doi.org/10.1080/13547860.2011.564746

ITU (International Telecommunication Union). 2019. ICT development statistics. [cited 2019 Dec 26]: Available from: https://www.itu.int/en/ITU-D/Statistics/Pages/stat/default.aspx

Javorcik, B. Smarzynska. 2004. Does foreign direct investment increase the productivity of domestic firms? In search of spillovers through backward linkages. American Economic Review; 94: 605-627. https://doi.org/10.1257/0002828041464605
Leontief, Wassily. 1941. Structure of American economy. New York: Oxford University Press.

Leontief, Wassily. 1953. Studies in the structure of the American economy. New York: Oxford University Press.

Leontief, Wassily. 1986. Input-output economics. $2^{\text {nd }}$ ed. Oxford: Oxford University Press.

Liu, Zhiqiang. 2002. FDI and technology spillovers: Evidence from China. Journal of Comparative Economics; 30 (3): 579-602. https://doi.org/10.1080/09535314.2018.1474182

MIC (Ministry of Information and Communication of Vietnam). 2009 White book: Vietnam Information and Communication 2009. Information and Communication Publishing.

MIC (Ministry of Information and Communication of Vietnam). 2019. White book: Vietnam Information and Communication 2019. Information and Communication Publishing.

Miller, Ronahn E., and Peter D. Blair. 2009. Input-output analysis foundations and extensions. $2^{\text {nd }}$ ed. New York: Cambridge University Press. https://doi.org/10.1017/CBO9780511626982

MOF (Ministry of Finance of Vietnam). 2019. Đánh giá thực trạng hoạt động của doanh nghiệp có vốn đầu tư nước ngoài và chính sách ưu đãi đầu tư hiện nay [Real Situation of FDI Enterprises and Current Preferential Policies of Vietnam]

Nagashima, Fumiya. 2018. The sign reversal problem in structural decomposition analysis. Energy Economics; 72: 307-312. https://doi.org/10.1016/j.eneco.2018.04.027

Newman, Carol, John Rand, Theodore Talbot, and FinnTarp. 2015 Technology transfers, foreign investment and productivity spillovers. European Economic Review; 76: 168-187. https://doi.org/10.1016/j.euroecorev.2015.02.005

OECD. 2009. Information economy product definitions based on the central product classification. Geneva: OECD Publishing.

Rai, Deepika. and Sherah Kurnia. 2017. Factors affecting the growth of the ICT industry: the case of Bhutan. $14^{\text {th }}$ International Conference on Social Implications of Computers in Developing Countries (ICT4D), May 2017, Yogyakarta, Indonesia: 728-739. https://doi.org/10.1007/978-3-319-59111-7 59

Rohman, Ibrahim K. 2013. The globalization and stagnation of the ICT sectors in European countries: An Input-output analysis. Telecommunications Policy; 37: 387-399. https://doi.org/10.1016/j.telpol.2012.05.001

Rose, Adam, and Stephen Casler. 1996. Input-output structural decomposition analysis: A critical appraisal. Economic Systems Review; 8 (1): 33-62. https://doi.org/10.1080/09535319600000003

Roy, Sikhanwita, and Debesh Chakraborty. 2005. Information sector and tenth five years plan of India. Review of Development and Change; $X(2): 119-140$ https://doi.org/10.1177/0972266120050202

Shirazi, Fraid. 2008. The impact of foreign direct investment and trade openness on ICT expansion. PACIS 2008 Proceedings: 148. http://aisel.aisnet.org/pacis2008/148

Tan, Felix B., and Kallaya Leewongcharoen. 2005. Factors contributing to IT industry success in developing countries: The case of Thailand. Information Technology for Development; 11 (2): 161-194. https://doi.org/10.1002/itdj.20009

Thai Khang. 2016. 4G deployment: Vietnam should not delay any more. ICT News, 24 August 2016. [cited on 2020 Mar. 30]. Available from: https://ictnews.vietnamnet.vn/vienthong/trien-khai-4g-viet-nam-khong-nen-cham-tre-nua142291.ict

Trinh, Bui, N.V. Phong, and Bui. Quoc. 2018. The RAS method with random fixed points. Journal of Economics and Business; 1(4), pp. 640-646.

https://doi.org/10.31014/aior.1992.01.04.57 
Vietnam Communist Party Central Committee. 2000. Directive 58CT/TW: Accelerating the use and development of information technology for the course of industrialization and modernization. 17 October 2000.

Vind, Ingeborg. 2008. Transnational companies as a source of skill upgrading: the electronics industry in Ho Chi Minh city. Geoforum; 39 (2008): 1480-1493.

https://doi.org/10.1016/j.geoforum.2008.01.005
UN (United Nation). 2008. International Standard Industrial Classification of all Economic Activities (ISIC), Rev. 4. Department of Economic and Social Affairs, Statistics Division, New York.

Received on 26-04-2020

Accepted on 21-08-2020

Published on 25-09-2020

DOI: https://doi.org/10.6000/1929-7092.2020.09.30

(C) 2020 Duc and Linh; Licensee Lifescience Global.

This is an open access article licensed under the terms of the Creative Commons Attribution Non-Commercial License (http://creativecommons.org/licenses/by-nc/3.0/) which permits unrestricted, non-commercial use, distribution and reproduction in any medium, provided the work is properly cited. 